\title{
Response of shallow subterranean freshwater amphipods to habitat drying
}

\author{
Heather Gilbert', Jenna Keany', David C. Culver' \\ I Department of Environmental Science, American University, 4400 Massachusetts Ave. NW, Washington, \\ DC 20016, USA \\ Corresponding author: David C. Culver (dculver@american.edu)
}

Academic editor: Oana Moldovan | Received 19October 2018 | Accepted30 October 2018 | Published 16 November 2018

http://zoobank.org/359479FF-F292-49B8-8B39-754E7E01739D

Citation: Gilbert H, Keany J, Culver DC (2018) Response of shallow subterranean freshwater amphipods to habitat drying. Subterranean Biology 28: 15-28. https://doi.org/10.3897/subtbiol.28.30700

\begin{abstract}
The ability of three amphipods that occupy shallow subterranean habitats in the lower Potomac Basin of the US (hypotelminorheic), which often dry out seasonally, to withstand desiccation by burrowing in clay was investigated. Both Crangonyx shoemakeri, a wetland species, and Stygobromus tenuis, a subterranean species, burrowed in clay in the laboratory after surface water was removed. Gammarus minus, a spring species, did not. All three species exhibited behavioral changes as the habitat dried out.
\end{abstract}

\section{Keywords}

Adaptation to desiccation, burrowing, Crangonyx shoemakeri, Gammarus minus, Hypotelminorheic, shallow subterranean habitats, Stygobromus

\section{Introduction}

Freshwater habitats, such as wetlands and seasonal streams, typically first order streams, are subject to drying. Water level patterns, or hydroperiods, are an important way to categorize wetland habitats (Jackson et al. 2014, Batzer and Boix 2016). Permanent wetlands differ from seasonal wetlands (e.g., Scheffer 2004, Zimmer et al. 2016) in that their inhabitants are adapted to deal with a significant loss of water for months at a time (Wiggins et al. 1980). These adaptations include resting stages, migration, and burrow- 
ing into substrates that hold moisture. The fauna of wetlands varies, and among the most ubiquitous macro-fauna are Chironomidae and Dystiscidae (Batzer and Ruhí 2013).

In contrast with wetland habitats, caves and other subterranean habitats are typically among the most environmentally stable freshwater ecosystems (Poulson 1964, Culver and Pipan 2009). Cave streams dry up well after surface streams because they are fed by shallow subsurface aquifers in the epikarst (Williams 2008). Nevertheless, not all aquatic cave habitats are permanent. Many drip pools in caves, perched well above any streams, are subject to periodic drying either because of increased evaporation in cave passages, especially during winter summer months, or because of small changes in the flow path of water moving through epikarst. The epikarst itself, which is not accessible to direct observation or sampling, harbors both terrestrial and aquatic species (Culver and Pipan 2014). This outfall of animals suggests that habitats may switch between aquatic and terrestrial with water movement. Ginet (1960) and Mathieu and Turquin (1992) point out that the drying of pools is a typical part of the environment of some cave-dwelling Niphargus amphipods. The subterranean macro-fauna is less varied than that of wetlands, and is dominated by crustaceans, especially amphipods and isopods (Gibert and Culver 2009).

Burrowing to avoid desiccation is well known among wetland invertebrates, especially among species that have no resting stage and are unable to disperse, such as amphipods (Wiggins et al. 1980; DiSalvo and Haynes 2015). However, there are few reports of burrowing behavior of cave amphipods. Ginet (1960) reported burrowing in the subterranean amphipod Niphargus virei, an inhabitant of isolated pools in caves in France, and Mathieu and Turquin (1992) summarized his observations. Gounot (1960) suggested that burrowing was actually the result of ingestion of clay for its nutritional value, perhaps some micronutrient given the generally low level of organic carbon in clay. Holsinger and Dickson (1977) observed burrowing behavior in Crangonyx antennatus, a cave pool inhabitant in Virginia caves, in the laboratory, of both populations from permanent and temporary cave waters. The temporary cave waters in this case were epikarst drip pools.

While there is little discussion of wetlands in the cave and karst literature (see Pipan and Culver 2012, Sheehy Skeffington and Gormally 2007, Skeffington and Scott 2008), and even less discussion of caves and karst in the wetlands literature (Reynolds 2016), there is a unique habitat that bridges the two categories - the hypotelminorheic. First described by Meštrov (1962), it is in essence, a superficial subterranean drainage (Pipan et al. 2012) and a miniature wetland at its exit. This definition was later expanded by Culver and Pipan (2014) to include:

- A persistent wet spot that may dry up seasonally

- Underlain by clay or other impermeable layer

- Water exiting via seepage flow, typically from a slight depression

- Presence of blackened leaves

- A subterranean fauna, with species lacking or having reduced eyes and pigment 
The hypotelminorheic is a subterranean habitat because it is aphotic except at its exit at a seep or seepage spring, where some light penetrates the leaf litter. We follow Williams' (2017) distinction between seeps and springs. He defines seeps as comprising groundwater that emerges over a more diffuse area [than springs], with a rate of flow that is generally insufficient to form an outflow spring. The exit point, or seep, is an isolated wetland, rich in organic carbon from decaying leaves, and is in turn habitat for amphipods. This, in many ways unremarkable habitat, is made remarkable by its fauna. Of the 56 species in the exclusively subterranean amphipod genus Stygobromus found in the eastern United States $12(21 \%)$ are found primarily in hypotelminorheic habitats (Culver et al. 2010). In turn, amphipods and isopods are the dominant macroorganisms of all studied hypotelminorheic habitats (Pipan et al. 2012). Many of these species are both troglomorphic (reduced or absent eyes and pigment, and elaborated appendages) and stygobiotic (limited to subterranean habitats).

With increased monitoring and sampling of seeps in the mid-Atlantic region of the U.S. (e.g., Culver et al. 2012), it became apparent that most seeps have no flow during the summer months (May to October). Whether the subterranean hypotelminorheic habitat also dries out is not directly known, but if the exit to these small aquifers is dry, then the amount of free water in the aquifer is likely reduced. During these drying periods, water is likely retained in the clay layer. The two key properties of clay are both its high porosity (nearly as high as soil) and high specific retention (Heath 1983). Given the water retention of clay, it is plausible that the amphipod and isopod inhabitants of hypotelminorheic habitats burrow into clay as a refuge during dry periods.

In the course of sampling seeps in parklands of Washington, DC, specifically in National Capital Parks-East (Piscataway, Oxon Cove, Anacostia, Fort Dupont, Shepherd Parkway, and others), it was found that the macro-crustacean fauna was dominated by two species of amphipods - Crangonyx shoemakeri and a Stygobromus species in the tenuis group - and the isopod Caecidotea kenki, (Keany et al. 2018). The Stygobromus species lacks eyes and pigment, and $C$. kenki and C. shoemakeri have reduced eyes and pigment. The undescribed species of Stygobromus is likely limited to the Anacostia River drainage in Washington, DC, and adjoining parts of Maryland. C. shoemakeri is a common inhabitant of wetlands in National Capital Parks-East and elsewhere in its range from southcentral Maryland to southcentral Virginia (Zhang and Holsinger 2003). While not adapted to subterranean life in any obvious way, $C$. shoemakeri has likely adapted to the periodic drying of seasonal wetland habitats where it is found. Occasionally, a third amphipod is found in seeps of the DC metro area, especially those with direct connections to permanent surface streams - Gammarus minus. G. minus is primarily found in springs, and a distinct morphological variant - Gammarus minus var. tenuipes - is common in cave streams (but not cave pools, Culver et al. 1995). It is rarely, if ever, a permanent inhabitant of hypotelminorheic habitats. The isopod Caecidotea kenki is found in seeps and other small groundwater fed habitats. It is known from the lower Potomac drainage around Washington, DC, as well as two caves in Pennsylvania (Culver et al. 2012). It is not considered further in this study, as our study species were limited to amphipods. 
Our goal in this study was to determine whether the ability to burrow into clay substrates is an important factor in determining the presence of Stygobromus species and Crangonyx shoemakeri in seeps and the general absence of Gammarus minus. In order to investigate this, we conducted laboratory experiments monitoring the behavior and success of the three amphipods when water was systematically removed from a clay-filled petri dish.

\section{Methods}

\section{Species}

Three species were studied - Crangonyx shoemakeri (Hubricht and Mackin), Gammarus minus (Say), and Stygobromus tenuis potomacus (Holsinger). S. tenuis potomacus was used rather than the undescribed species from the tenuis group because there were not sufficient specimens of the undescribed species available. The two species are very similar morphologically and ecologically. All three species were found in seeps in the parklands of the District of Columbia, although G. minus was only found in seepage springs, typically with a permanent outflow, and usually during the Spring when water levels were at their highest.

Specimens used in this study were taken from seeps and springs in C \& O Canal National Historic Park under permit CHOH-2016-SCI-0023. These individuals were obtained using standard collecting procedures as described by Holsinger (1972). Early trials were completed using animals from Oxon Run in National Capital Parks-East under permit NACE-2016-SCI-0002. Unused animals were returned to their habitat.

\section{Laboratory methods}

The behavioral study was conducted in a Forma-lab Walk-in Environmental Room with a constant temperature of $5{ }^{\circ} \mathrm{C}$. Glass pyrex dishes, with a volume of approximately $470 \mathrm{~mL}$, (10 cm diameter and $4 \mathrm{~cm}$ depth) were lined with $30 \mathrm{~g}$ of dry VWR ${ }^{\mathrm{TM}}$ clay, creating a clay layer approximately $2 \mathrm{~cm}$ deep. This clay was homogenized using a mortar and pestle and was sifted through a $125 \mu \mathrm{m}$ mesh sieve to ensure consistent grain size. Sixty $\mathrm{mL}$ of Deer Park $^{\mathrm{TM}}$ spring water were added to each of the glass pyrex dishes, creating a water depth of approximately $2 \mathrm{~cm}$.

The three species of amphipods - S. tenuis potomacus, C. shoemakeri and G. minus - were studied separately. Within one week from the date of specimen collection, five individuals, all adults, of the same species were added to each dish. Ovigerous females were not used. After a 48 hour period of acclimation to the pyrex dishes, the trials began. This acclimation period was chosen based on the 2-10 day amphipod acclimation period recommended by Environment Canada (1993) and Swartz et al. (1985). 
Six dishes were designated for each species; three served as the control while the other three were used as experimental dishes that simulated drying conditions. Each trial lasted five weeks.

A supplemental experiment was completed to determine the amount of water loss (retention) of the clay over the course of eight weeks. The dry weight of the clay was compared to the weight of the clay after one to eight weeks of drying. Measurements began at the end of week 1 , after all surface water was removed.

During the course of the drying experiment, behavioral observations were made for 60 second intervals three times a week. The following behaviors were recorded if one or more individuals was observed with this behavior during the 60 second interval:

1 Walking (at least one body length)

2 Swimming (at least one body length)

3 Burrowing (direct observation or buried in clay)

4 Resting (resting for more than 10 seconds)

5 Interaction (with other amphipods)

6 Other (amplexus,etc.)

The relative frequency of these behaviors is not a direct measure of the time spent at each behavior because a behavior was given the same weight whether one or five amphipods was displaying the behavior. This indirect measure was necessary because it was impossible to track each individual separately. All observations were made under red light.

\section{Data analysis}

Both survival and behavioral data were analyzed used log-likelihood tests (G-tests), comparing observed and expected values in each category (e.g., walking in control dishes). G, which is distributed as $\chi^{2}$ was calculated as follows:

$$
G=2 \sum_{i} O_{i} \ln \left(O_{i} / E_{i}\right)
$$

where $O_{i}$ is the observed number of cases in category $i$ and $E_{i}$ is the expected number of cases in category $i$.

\section{Results}

Gravimetric measurement of moisture levels of the clay at the start of each trial averaged at $65.5 \%$ and reduced to an average of $54.2 \%$ after the first week of drying. 
Table I. Results of experiments on effect of drying. All runs began with 15 individuals.

\begin{tabular}{|c|c|c|c|c|c|c|}
\hline Species & Start of Trial & $\begin{array}{c}\text { Control- } \\
\text { surviving at } 4 \\
\text { weeks }\end{array}$ & $\begin{array}{c}\text { Experiment- } \\
\text { surviving at } 4 \\
\text { weeks }\end{array}$ & Difference & $\begin{array}{c}\text { Log- } \\
\text { likelihood }\end{array}$ & $\mathbf{p}$ \\
\hline \multirow{6}{*}{ Gammarus minus } & $7 / 20 / 2016$ & 15 & 8 & -7.00 & 5.15 & $<0.05$ \\
\hline & $7 / 20 / 2016$ & 15 & 7 & -8.00 & 4.44 & $<0.05$ \\
\hline & $8 / 9 / 2016$ & 15 & 10 & -5.00 & 3.45 & $<0.10$ \\
\hline & $1 / 8 / 2017$ & 2 & 2 & 0.00 & 0.00 & ns \\
\hline & $1 / 8 / 2017$ & 1 & 2 & 1 & 0.27 & ns \\
\hline & Total & 48 & 29 & -19 & 7.61 & $<0.010$ \\
\hline \multirow{6}{*}{ Crangonyx shoemaker } & $7 / 20 / 2016$ & 13 & 12 & -1 & 0.53 & ns \\
\hline & $8 / 9 / 2016$ & 15 & 15 & 0 & 0.00 & ns \\
\hline & $1 / 8 / 2017$ & 15 & 15 & 0 & 0.00 & ns \\
\hline & $1 / 8 / 2017$ & 15 & 15 & 0 & 0.00 & ns \\
\hline & $1 / 8 / 2017$ & 12 & 15 & 3 & 1.95 & ns \\
\hline & Total & 70 & 72 & 2 & 0.25 & ns \\
\hline \multirow{4}{*}{$\begin{array}{l}\text { Stygobromus tenuis } \\
\text { potomacus }\end{array}$} & $7 / 20 / 2016$ & 14 & 15 & 1 & 0.62 & ns \\
\hline & $1 / 8 / 2017$ & 15 & 15 & 0 & 0.00 & ns \\
\hline & $1 / 8 / 2017$ & 15 & 15 & 0 & 0.00 & ns \\
\hline & Total & 44 & 45 & 1 & 0.61 & ns \\
\hline
\end{tabular}

Moisture levels then reduced to $34.4 \%$ at week two, and remained relatively consistent from week two to week nine, at around 30\% (Fig. 1).

Overall, there was a $25 \%$ increase in mortality for G. minus when subjected to drying (Table 1), which was a statistically significant difference between experiment and control $(\mathrm{G}=7.61, \mathrm{p}<0.01)$. The difference was especially striking in the first three trials where no control animals died, and $44 \%$ of the amphipods died in the experimental treatment. In the last two trials, only a few amphipods survived (23\%) in either experiment or control treatments. We cannot account for this difference between the first three and the last two experiments, but the high mortality suggests some water quality problem. However, no increased mortality was recorded for the other species. Both $C$. shoemakeri and $S$. tenuis potomacus showed the identical pattern of little or no mortality in either experiment or control (Table 1). For C. shoemakeri only $4 \%$ of experimental animals died, slightly fewer than the number of control animals that died. For $S$. tenuis potomacus, there was no mortality in the experimental treatments, and only one amphipod died in the control (Table 1). Thus, only G. minus had significant mortality associated with the drying experiment, and there were no differences in the survival of C. shoemaker and S. tenuis potomacus.

The three species showed differences in behavior, both between experiment and control, but also between species (Fig. 2, Table 2). In the controls, all three species showed frequent interaction (between $30 \%$ and $40 \%$ of the observational periods had one or more interactions) with other individuals, typically avoidance behavior (see Culver 1970). Locomotory behavior was observed about half the time, typically swimming in the case of $G$. minus and walking in the case of $C$. shoemakeri. Somewhat surprisingly, S. tenuis potomacus was equally likely to swim or walk, even 


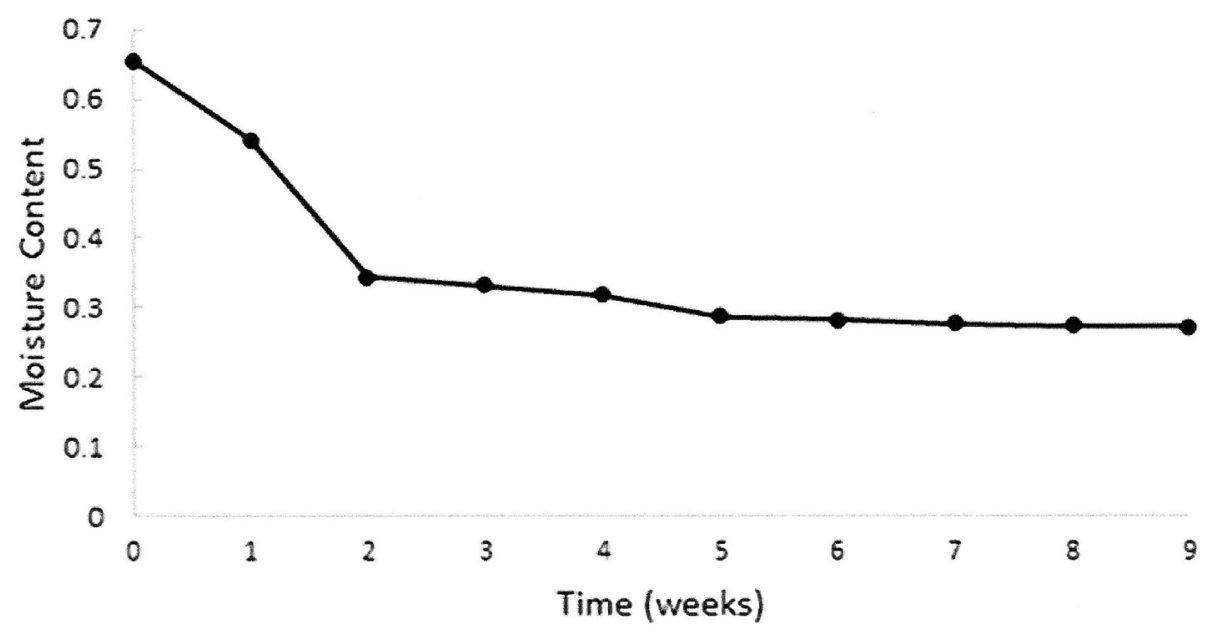

Figure I. Average gravimetric soil moisture over the nine week trial.

though species in the genus are weak swimmer and usually walk (Culver 1970). Resting was uncommon in all three species in control containers, occurring less than $10 \%$ of the time (Fig. 2). G. minus were in amplexus $12 \%$ of the time. This behavior was particularly frequent in the last two control trials. Overall, in the control containers, the three species had differences in behavior (Table 3) due to species specific behavioral patterns in locomotion (swimming vs. walking) and amplexus (only with G. minus).

When in the experimental containers, each species showed statistically significant differences in behavior relative to the control containers (Table 3). G. minus showed decreases in all categories except inactivity, which was observed $85 \%$ of the time (Fig. 2, Table 2). Typically, the G. minus animals were stretched out on the substrate and burrowing was only observed once. Amplexing was a particularly frequent behavior in the last two trials, perhaps due to seasonality of mating behavior.

For $C$. shoemakeri, resting was also the most common activity, occurring $77 \%$ of the time (Fig. 2). In comparison with resting $G$. minus, resting $C$. shoemakeri curled into ' $\mathrm{C}$ ' shapes keeping their appendages tight to their bodies. Burrowing, and residence in burrows was the second most common activity, occurring $10.4 \%$ of the time. Not surprisingly, swimming almost completely disappeared (less than 1\%) and walking was observed only $9.4 \%$ of the time, given that there was no open water (Fig. 2).

Overall, S. tenuis potomacus showed less behavioral change than the other two species, but the differences were statistically significant compared to its control group (Table 2). Resting was the most common behavior in the experimental conditions, occurring $42.1 \%$ of the time, but was still less frequent when compared to resting in the other two species. Walking and interaction remained common, although less so than in controls, 


\section{Gammarus minus}



\section{Crangonyx shoemakeri}

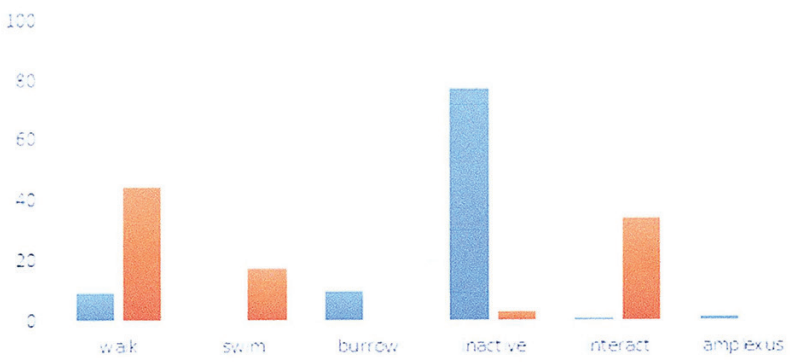

Stygobromus tenuis potomacus

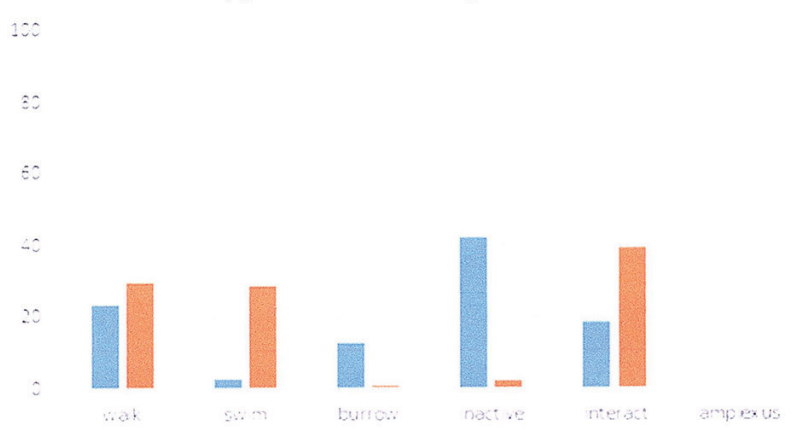

Figure 2. Relative frequency of different behaviors of the three species in control (red bars) and experimental (blue bars).

and swimming declined to less than 3\% (Fig. 2, Table 2). Burrowing (and residence in burrows) was relatively frequent in S. tenuis potomacus, accounting for $12.9 \%$ of observations in the experimental group. The burrows of $S$. tenuis potomacus were deeper than those of C. shoemakeri, but they both had a similar C-shape when resting. S. tenuis potomacus leave circular depressions visible from the top of the soil where they have entered the clay. They exhibit the greatest amount of burrowing and travel the deepest into the clay; one $S$. tenuis potomacus hole was visible from the bottom of the dish. 
Table 2. Number of observations of six different behaviors of Crangonyx shoemakeri, Gammarus minus, and Stygobromus tenuis potomacus in experimental and control containers. If at least one individual (and up to five) shows the behavior, this is counted as an observation. See methods for the observational protocols.

\begin{tabular}{lcccccc}
\hline \multirow{2}{*}{ Category } & \multicolumn{2}{c}{ Gammarus } & \multicolumn{2}{c}{ Crangonyx } & \multicolumn{2}{c}{ Stygobromus } \\
\cline { 2 - 7 } & Exp & Control & Exp & Control & Exp & Control \\
\hline 1- walk & 3 & 20 & 19 & 138 & 40 & 55 \\
2-swim & 3 & 125 & 1 & 54 & 5 & 53 \\
3-burrow & 1 & 2 & 21 & 0 & 22 & 1 \\
4-resting & 161 & 24 & 156 & 10 & 72 & 4 \\
5-interact & 8 & 88 & 2 & 106 & 32 & 73 \\
6-amplexus & 11 & 34 & 3 & 0 & 171 & 186 \\
Total & 189 & 293 & 202 & 308 & & 0 \\
\hline
\end{tabular}

Table 3. Log-likelihood tests for differences between behaviors in experimental and control containers for Crangonyx shoemakeri, Gammarus minus, and Stygobromus tenuis potomacus, and among control behavior and among behavior in experimental containers. $\mathrm{n}_{1}, \mathrm{n}_{2}$, and $\mathrm{n}_{3}$ are the total number of observations of a behavior, e.g., walking. The total number of separate observations was 180 for G. minus and C. shoemakeri; 108 for S. tenuis potomacus. For some observation periods more than one behavior was observed. See Figure 1.

\begin{tabular}{lcccccc}
\hline \multicolumn{1}{c}{ Comparison } & $\mathbf{n}_{1}$ & $\mathbf{n}_{2}$ & $\mathbf{n}_{3}$ & df & log - likelihood & p \\
\hline G. minus-experiment vs. control $^{2}$ & 188 & 291 & & 4 & 147.6 & $<0.01$ \\
${\text { C. } \text { shoemakeri-experiment vs. control }^{1}}$ & 199 & 308 & & 4 & 198,9 & $<0.01$ \\
S. t. potomacus-experiment vs. control $^{1}$ & 171 & 186 & & 4 & 70.4 & $<0.01$ \\
All control $^{\text {All experimental }}$ & 308 & 291 & 186 & 10 & 112.1 & $<0.01$ \\
\hline
\end{tabular}

${ }^{1}$ Amplexus is excluded due to small sample size.

${ }^{2}$ Burrowing is excluded due to small sample size.

\section{Discussion}

\section{Adaptation to the absence of open water}

Crangonyx shoemakeri and Stygobromus tenuis potomacus have evolved mechanisms allowing for their success in habitats that periodically lack open water. Both of these species exhibited similar adaptations by burrowing into the substrate during experimental drying periods. Those individuals that failed to burrow, remaining exposed on the surface, curled in ' $\mathrm{C}$ ' shapes and often times lay in shallow depressions. The length of time that burrowing in clay can provide a refuge from desiccation is unknown, beyond the four week duration of the experiment. We do know that moisture is retained in clay for longer periods (see Fig. 1).

Animals living in surface habitats that periodically dry, including many wetlands, have a large array of strategies to cope with desiccation (Wiggins et al. 1980). Crangonyx is a frequent inhabitant of wetlands (Boix and Baxter 2016), and Wiggins et al. (1980) report that $C$. gracilis uses crayfish burrows as refuges from desiccation. Wiggins et al. (1980) report that $C$. rivularis burrows into sediments and bottom vegeta- 
tion during the absence of open water in summer and autumn. DiSalvo and Haynes (2015) describe an interesting strategy employed by $C$. pseudogracilis in temporary pools. During wet weather they actively enter existing small tubes in the soil, and are able to persist throughout the year in damp soil. Unfortunately, no phylogeny exists for Crangonyx and so we cannot look directly at evolutionary relationships of this behavior.

In addition to its widespread occurrence in wetlands, Crangonyx is also a frequent inhabitant of caves and some of these species occur in epikarst drip pools, a subterranean habitat that occasionally dries out (Pipan and Culver 2013). Holsinger and Dickson (1976) observed burrowing behavior in an epikarst drip pool population of Crangonyx antennatus in Molly Waggle Cave in Virginia.

The only other observations of burrowing behavior in subterranean habitats comes from the European amphipod genus Niphargus. Ginet (1960) observed Niphargus curling into a ' $\mathrm{C}$ ' shape in a shallow burrow where individuals were at least partially visible from the surface (see also Mathieu and Turquin 1996). Interestingly, they reported that an air bubble was typically present on the dorsal side, presumably aiding in oxygen exchange. It remains unknown if either Stygobromus tenuis potomacus or Crangonyx shoemaker form such air bubbles, but none were directly observed. Gounot (1960) asserted that the clay supplies important nutrients from the presence of inert organic substances as well as microorganisms. She based this on experiments where survival was enhanced when Niphargus virei was provided a clay substrate compared to the control where no substrate was provided. Gounot showed that while the nutrients associated with clay were needed for immature Niphargus, they are not sufficient as the only source of nutrients for adults. To our knowledge, these preliminary experiments have never been followed up.

\section{Conservation and protection}

Clay substrates provide important resources for amphipod species from nutrition to surviving environmental stressors. Our findings indicate the importance of a clay layer for Crangonyx shoemakeri and Stygobromus tenuis potomacus amphipods inhabiting hypotelminorheic habitats in the Washington, DC region. To protect these species and the endemic and endangered species, Stygobromus hayi, it is essential to maintain healthy soil. Although these cryptic species may not be found during drying periods, it is apparent that the animals are still present. Due to the difficulty in accessing the microenvironments these animals create in the soil, biological surveys may report false negatives. The application of eDNA sampling holds promise for detecting these populations (Niemiller 2017).

By 2090, it is expected that the proportion of the global land surface in extreme drought will increase tenfold from current levels (Kundzewicz et al. 2008). Due to the extension of droughts and decreasing water levels, wetlands are at risk. While some of these wetlands are ephemeral and therefore not always wet, they constitute a large portion of the Earth's freshwaters and support freshwater biodiversity (Williams 2006). As a result of wetland global significance to healthy ecological systems, climate-driven changes to wetland hydrology have been identified as a key global wetland conservation issue (Klein 
et al. 2005; Waterkeyn et al. 2008). Records of river and wetland hydroperiods already indicate pronged and more frequent dry periods (Strachan et al. 2014). These measurements are two components of a hydroregime. The characteristics of a particular hydroregime, particularly the hydroperiod, have a direct influence on aquatic community structure and its biodiversity (Brooks 2000; Williams 2006; Vanschoenwinkel et al. 2009).

In Australia, Sim et al. (2013) examined long-term data sets of temporal trends in the persistence and the stability of freshwater ecosystems and documented changes in wetland hydroperiods over the past 50 years. At one site, the hydroperiod was significantly correlated with invertebrate community richness. Ultimately, however, the study could not capture the true effects of long term drying. The magnitude of drying on these communities is yet to be fully recorded. As successive hydroperiods decrease without sufficient time and recharge, the flexibility of invertebrate survival strategies will be tested. Small wetlands that facilitate movement of species on a landscape scale may completely dry, leaving exposed the many species that rely on migrating to nearby permanent water after ephemeral habitats dry (Sim et al. 2013). This loss of water is cited as one of the most deleterious of environmental changes, changing the patch dynamics of species. As species geographic range is reduced, metapopulations will be altered (Robson et al. 2011). If surface water disappears completely, this would signify the end of the corresponding habitat niche, and only those inhabitants capable of surviving without even intermittent surface water could persist in the long term.

In order to further assess the impact these anthropogenic changes to the environment will have on amphipod species, it is necessary to learn more about thair physiological sensitivity. To better understand amphipod adaptations and estimate the impact of warming on their fitness, further studies on the burrowing behavior of Crangonyx shoemakeri and Stygobromus tenuis potomacus should be investigated.

\section{Acknowledgements}

This research was supported by Chesapeake Watershed Cooperative Ecosystem Studies Unit Cooperative Agreement P16AC01389 between Department of the Interior, National Park Service, National Capital Parks - East and American University, "A Survey of the Fauna of Seepage Springs in National Capital Parks-East (NACE)". All specimens were collected under CHOH-2016-SCI-0023 and NACE-2016-SCI-0002 permits. A reviewer offered many constructive comments.

\section{References}

Abessa D, Sousa EC, Rachid BR, Mastroti RR (1998) Use of the burrowing amphipod Tiburonella viscana as a tool in marine sediments contamination assessment. Brazilian Archives of Biology and Technology 41(2): 225-230. https://doi.org/10.1590/S1516-89131998000200009 
Batzer DP, Boix D (2016) An introduction to freshwater wetlands and invertebrates. In: Batzer DP, Boix D (Eds) Invertebrates in Freshwater Wetlands. An international perspective on their ecology. Springer, Cham, 1-24. https://doi.org/10.1007/978-3-319-24978-0_1

Batzer DP, Ruhí A (2013) Is there a core of organisms that structure macroinvertebrate assemblages in freshwater wetlands? Freshwater Biology 58(8): 1647-1659. https://doi. org/10.1111/fwb.12156

Brooks RT (2000) Annual and seasonal variation and the effects of hydroperiod on benthic macroinvertebrates of seasonal forest ("vernal") ponds in Central Massachusetts, USA. Wetlands 20: 707-715. https://doi.org/10.1672/0277-5212(2000)020[0707:AASVAT] 2.0.CO;2

Culver DC (1970) Analysis of simple cave communities: niche separation and species packing. Ecology 51(6): 949-958. https://doi.org/10.2307/1933622

Culver DC, Holsinger JR, Christman MC, Pipan T (2010) Morphological differences among eyeless amphipods in the genus Stygobromus dwelling in different subterranean habitats. Journal of Crustacean Biology 30(1): 68-74. https://doi.org/10.1651/09-3156.1

Culver DC, Holsinger JR, Feller DJ (2012) The fauna of seepage springs and other shallow subterranean habitats in the mid-Atlantic Piedmont and Coastal Plain, U.S.A. Northeastern Naturalist 19(Monograph 9): 1-42. https://doi.org/10.1656/045.019.m901

Culver DC, Kane TC, Fong DW (1995) Adaptation and natural selection in caves: the evolution of Gammarus minus. Harvard University Press, Cambridge, 223 pp. https://doi. org/10.4159/harvard.9780674419070.c9

Culver DC, Pipan T (2009) Biology of caves and other subterranean habitats. Oxford University Press, Oxford, 254 pp. https://doi.org/10.5860/CHOICE.47-1398

Culver DC, Pipan T (2014) Shallow subterranean habitats: ecology, evolution, and conservation. Oxford University Press, Oxford, 258 pp. https://doi.org/10.1093/acprof:o so/9780199646173.001.0001

DiSalvo B, Haynes J (2015) Colonization and persistence of Crangonyx gracilis (Bousfield 1958) in temporary pools. Freshwater Science 34(2): 547-554. https://doi.org/10.1086/680986

Environment Canada (1992) Biological test method: acute test for sediment toxicity using marine or estuarine amphipods. Report EPS1/RM/26, Ottawa, 83 pp.

Gibert J, Culver DC (2009) Assessing and conserving groundwater biodiversity: an introduction. Freshwater Biology 54(4): 639-648. https://doi.org/10.1111/j.1365-2427.2009.02202.x

Ginet R (1960) Ecologie, ethologie et biologie de Niphargus (Amphipodes Gammaridés hypogés). Annales de Spéléologie 15: 1-254.

Gounot AM (1960) Recherches sur le limon argileux souterrain et sur son role nutritive pour les Niphargus. Annales de Spéléologie 15: 501-526.

Heath RC (1983) Basic ground-water hydrology. United States Geological Survey Water Supply Paper 2220, Alexandria, 85 pp. https://doi.org/10.3133/wsp2220

Holsinger JR (1972) The Freshwater amphipod crustaceans (Gammaridae) of North America. Biota of Freshwater Ecosystems Identification Manual No. 5, Environmental Protection Agency, Washington, DC.

Holsinger JR, Culver DC (1970) Morphological variation in Gammarus minus Say (Amphipoda, Gammaridae), with emphasis on subterranean forms. Postilla No. 146, 24 pp. 
Holsinger JR, Dickson GW (1977) Burrowing as a means of survival in the troglobitic amphipod crustacean Crangonyx antennatus Packard (Crangonyctidae). Hydrobiologia 54(3): 195-199. https://doi.org/10.1007/BF00014284

Jackson CR, Thompson JA, Kolka RK (2014) Wetland soils, hydrology, and geomorphology. In: Batzer DP, Sharitz RR (Eds) Ecology of freshwater and estuarine wetlands, second edition. University of California Press, Berkeley, 23-60. https://doi.org/10.1525/california/9780520247772.001.0001

Klein E, Berg EE, Dial R (2005) Wetland drying and succession across the Kenai Peninsula Lowlands, southcentral Alaska. Canadian Journal of Forest Research 35(8): 1931-1941. https://doi.org/10.1139/x05-129

Kundzewicz ZW, Mata LJ, Arnell NW, Doll P, Jimenez B, Miller K, Oki T, Sen Z, Shiklomanov I (2008) The implications of projected climate change for freshwater resources and their management. Hydrological Science 53(1): 3-11. https://doi.org/10.1623/hysj.53.1.3

Marzolf RG (1965) Substrate relations of the burrowing amphipod Pontoporeia affinis in Lake Michigan. Ecology 46(5): 580-592. https://doi.org/10.2307/1934998

Mathieu J, Turquin MJ (1992) Biological processes at the population level. II. Aquatic populations: Niphargus (stygobiont amphipod) case. In: Camacho AI (Ed.) The Natural History of Biospeleology. Monografias Museo Nacional de Ciencias Naturales, Madrid, 263-294.

Meštrov M (1962) Un nouveau milieu aquatique souterrain: le biotope hypotelminorheique. Compte Rendus de l'Académie des Sciences, Paris 254: 2677-2679.

Pipan T, Culver DC (2012) Wetlands in cave and karst regions. In: White WB, Culver DC (Eds) Encyclopedia of Caves. Second Edition. Elsevier/Academic Press, Amsterdam, 897904. https://doi.org/10.1016/B978-0-12-383832-2.00129-8

Pipan T, Fišer C, Novak T, Culver DC (2012) Fifty years of the hypotelminorheic: what have we learned? Acta Carsologica 42(2-3): 275-285. https://doi.org/10.3986/ac.v41i2-3.564

Ponznanska M, Kakareko T, Krzyzynski M, Kobak J (2013) Effect of substratum drying on the survival and migrations of Ponto-Caspian and native gammarids (Crustacea: Amphipoda). Hydrobiologia 700(1): 47-59. https://doi.org/10.1007/s10750-012-1218-6

Poulson TL (1964) Animals in aquatic environments: animals in caves. In: Dill DP (Ed.) Handbook of Physiology. American Physiological Society, Washington, DC.

Reynolds JD (2016) Invertebrates of Irish turoughs. In: Batzer DP, Boix D (Eds) Invertebrates in Freshwater Wetlands. An International perspective on their ecology. Springer, Cham, 191-218. https://doi.org/10.1007/978-3-319-24978-0_6

Robson B, Chester E, Austin C (2011) Why life history information matters: drought refuges and macroinvertebrate persistence in non-perennial streams subject to a drier climate. Marine and Freshwater Research 62(7): 801-810. https://doi.org/10.1071/MF10062

Scheffer M (2004) Ecology of shallow lakes. Kluwer, Dordrecht, 357 pp. https://doi. org/10.1007/978-1-4020-3154-0

Sheehy Skeffington M, Gormally M (2007) Turloughs: a mosaic of biodiversity and management systems unique to Ireland. Acta Carsologica 36(2): 217-222. https://doi. org/10.3986/ac.v36i2.190

Sheehy Skeffington M, Scott NE (2008) Do turloughs occur in Slovenia? Acta Carsologica 37(2-3): 291-306. https://doi.org/10.3986/ac.v37i2-3.153 
Sim LL, Davis JA, Strehlow K, McGuire M, Trayler KM, Wild S, Papas PJ, O’Connor J (2013) The influence of changing hydroregime on the invertebrate communities of temporary seasonal wetlands. Freshwater Science 32(1): 327-342. https://doi.org/10.1899/12-024.1

Strachan SR, Chester ET, Robson BJ (2014) Microrefuges from drying for invertebrates in a seasonal wetland. Freshwater Biology 59(12): 2528-2538. https://doi.org/10.1111/ fwb. 12451

Swartz EC, Deden WA, Sercu KA, Lamberson JO (1982) Sediment toxicity and the distribution of the amphipods in Commencement Bay, Washington, USA. Marine Pollution Bulletin 13(10): 259-264. https://doi.org/10.1016/0025-326X(82)90041-8

Vanschoenwinkel B, Hulsmans A, De Roeck E, De Vries C, Seaman M, Brendonck L (2009) Community structure in temporary freshwater pools: disentangling the effects of habitat size and hydroregime. Freshwater Biology 54(7): 1487-1500. https://doi.org/10.1111/ j.1365-2427.2009.02198.x

Waterkeyn A, Grillas P, Vanschoenwinkel B, Brendonck L (2008) Invertebrate community patterns in Mediterranean temporary wetlands along hydroperiod and salinity gradients. Freshwater Biology 53(9): 1808-1822. https://doi.org/10.1111/j.1365-2427.2008.02005.x

Wiggins GB, Mckay RJ, Smith IM (1980) Evolutionary and ecological strategies of animals in annual temporary pools. Archiv für Hydrobiologie Supplement 58: 97-206.

Williams DD (2016) Invertebrates in groundwater springs and seeps. In: Batzer DP, Boix D (Eds) Invertebrates in freshwater wetlands. An international perspective on their ecology. Springer, Cham, 357-410. https://doi.org/10.1007/978-3-319-24978-0_11

Williams PW (2008) The role of epikarst in karst and cave hydrology: a review. International Journal of Speleology 37(1): 1-10. https://doi.org/10.5038/1827-806X.37.1.1

Zhang J, Holsinger JR (2003) Systematics of the freshwater amphipod genus Crangonyx in North America. Memoirs of the Virginia Museum of Natural History 6: 1-274.

Zimmer KD, Hanson MA, Wrubleski DA (2016) Invertebrates in permanent wetlands (longhydroperiod marshes and shallow lakes). In: Batzer DP, Boix D (Eds) Invertebrates in freshwater wetlands. An international perspective on their ecology. Springer, Cham, 251286. https://doi.org/10.1007/978-3-319-24978-0_8 